\title{
Comparative Analysis of the C4.5 Algorithm and the Nearest Neighbor for the Number of Prospective New Student Registrants
}

\author{
Nursetia Wati ${ }^{1}$, Irawan Ibrahim ${ }^{1}$ \\ *Correspondence: nursetiawati@umgo.ac.id \\ ${ }^{1}$ Faculty of Engineering, Information System Department, Muhammadiyah University of \\ Gorontalo, Indonesia
}

\begin{abstract}
In 2015, the number of registrants for new student candidates at Muhammadiyah University of Gorontalo, has increased about 20\% - 50\% from the last year in 2014, but when it starts from 2017/2018 of the academic year the number of new student candidates who registered was only around 4,713 students for bachelor's and there is 1,256 students for Bachelor's Degree, while in the academic year of 2018/2019 bachelor's degree students were only 765 and bachelor's students were around 4,187, it is known as a decline from the previous year. This study, aims to help to predict the number of prospective of the new students who will enroll in the following of the academic year by analyzing the comparison of the C4.5 and Nearest Neighbor Algorithms with comparing two of algorithms to get the best results. In the C4.5 and Nearest Neighbor Algorithms, it is necessary to be able to see some patterns from the data about the prospective students, then, they can produce the predictions of the number of prospective students who can help in increasing the number of prospective students that is according to the target achievements of Muhammadiyah University of Gorontalo (UMG) itself.
\end{abstract}

Keywords: Prediction, C4.5, Nearest Neighbor

Received : January 12, 2021

Received in Revised: February 8, 2021

Accepted: February 19, 2021

\section{Introduction}

Muhammadiyah University of Gorontalo is one of the private universities in Gorontalo, which has been established for more than one decade and, in 2018 with the number of students in the 2015/2016 of the academic year it is experienced a very significant increase that around six hundred (600) students who were accepted. In addition, in every new academic year, the University regularly holds the New Student Admissions activities. This new student admission activity has been routinely carried out, then it will indirectly collect a lot of data from the prospective new students themselves, therefore, in this case what the University needs to do is process of the data that came from all prospective students, then later it will becomes an important information. Based on this information, one of the data that can be generated is the target of the number of new student candidates itself.

The main problem that always continues and becomes an obstacle is, the large of the number of students who register, but, somehow the university cannot predict the number of prospective students who will re-register. This is can be seen in the number of students who entered in the 2017/2018 run into a drastic decline, this is because the private universities are not always become the first choices from prospective students that has been accepted at State Universities. 
Data Mining is a sequence of several processes to find an added value from a data set in the form of knowledge that is currently unknown manually (Retnosari \& Jananto, 2013; Kurgan $\&$ Musilek, 2006). Whereas, prediction itself is the process of forecasting future events that based on certain parameters to reduce uncertainty of a condition and create a benchmark to predict future events based on patterns that have occurred in the past (Hartatik, 2015; Mariscal et al, 2010).

In this study, one of the methods that is contained in Data Mining science will be applied, it is a prediction by analyzing the comparison of the C4.5 and Nearest Neighbor algorithms, which is expected by doing this forecasting or prediction model to obtain the best value by looking at the highest level of accuracy of the two algorithms which later can be use by Muhammadiyah University of Gorontalo in predicting the number of new student candidates who re-register and determine policies for the upcoming events of the admission of new students.

\section{Methods}

In this method of research, the researcher uses an analysis method that is based on CRISPDM (CRoss-Industry Standard Process for Data Mining) (Kusrini, 2009)

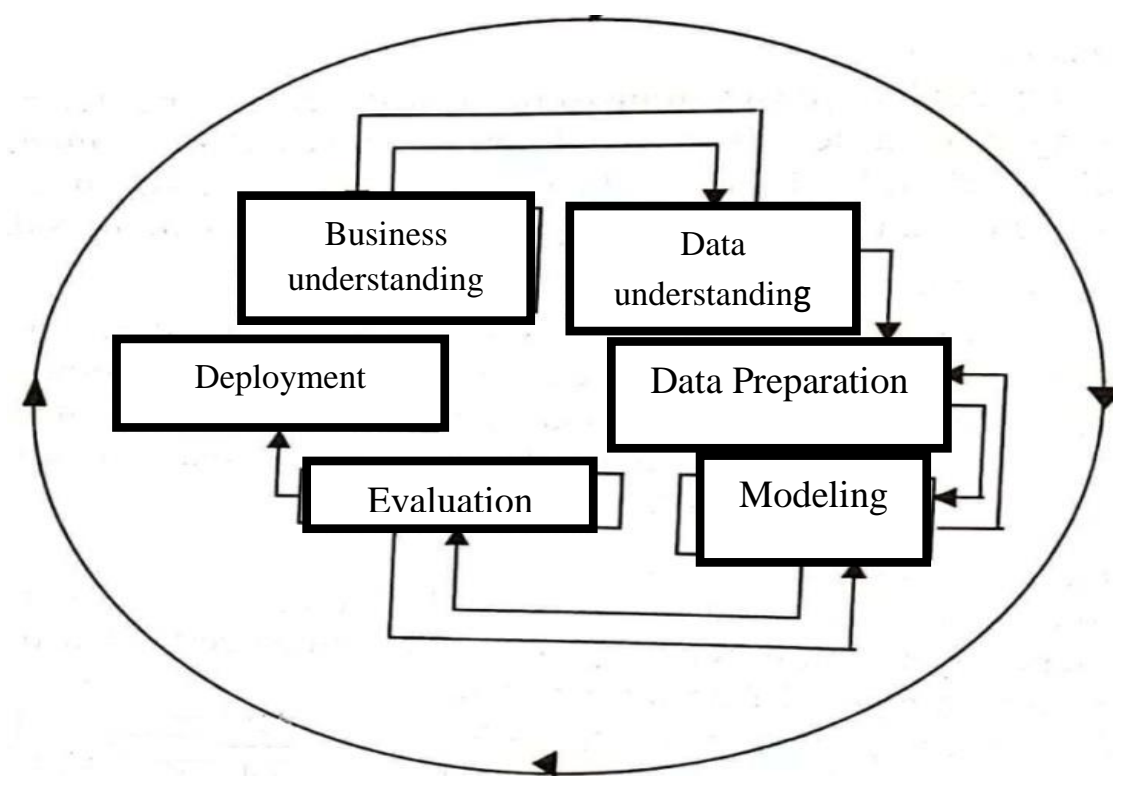

Figure 1. Data Mining Process According to CRISP-DM

The following sentence below is an explanation of the six stages of the data mining development life cycle based on the CRISP-DM (CRoss-Industry Standard Process for Data Mining):

\section{The Business Understanding}

At this stage the research aims to identify needs in detail, namely by identifying the patterns of the previous student admissions dataset based on the variables that have been selected, as shown in the table below: 


\begin{tabular}{|l|l|l|l|}
\hline Gender & \multicolumn{1}{|c|}{ Address } & \multicolumn{1}{|c|}{ Major } & $\ldots .$. \\
\hline Female & $\begin{array}{l}\text { Luwo'o Villace, sub-district of Telaga } \\
\text { Jaya }\end{array}$ & Language & \\
\hline Female & $\begin{array}{l}\text { Pantungo Village, sub-district of } \\
\text { Telaga Biru }\end{array}$ & Nursing & \\
\hline Male & $\begin{array}{l}\text { Bulota Village, sub-district of Telaga } \\
\text { Jaya }\end{array}$ & Social Sciences (IPS) & \\
\hline
\end{tabular}

\section{Data Understanding}

In collecting the data in this study, the researcher gets the data from prospective new students of Muhammadiyah University of Gorontalo that from 2015-2017 were obtained from the Admission of New Students in Muhammadiyah University of Gorontalo team, as in the table below:

\section{Enthusiasts}

\begin{tabular}{|l|l|c|c|c|c|l|}
\hline Year & $\begin{array}{l}\mathbf{1}^{\text {st }} \\
\text { Sequence }\end{array}$ & $\begin{array}{l}\mathbf{2}^{\text {nd }} \\
\text { Sequence }\end{array}$ & $\begin{array}{l}\mathbf{3}^{\text {rd }} \\
\text { Sequence }\end{array}$ & $\begin{array}{l}\mathbf{4}^{\text {rt }} \\
\text { Sequence }\end{array}$ & $\mathbf{5}^{\text {th }}$ Sequence & Sum \\
\hline 2015 & 415 & 79 & 105 & 130 & 319 & 1048 \\
\hline 2016 & 675 & 269 & 250 & 177 & 15 & 1386 \\
\hline 2017 & 239 & 201 & 771 & 259 & - & 1470 \\
\hline
\end{tabular}

\begin{tabular}{|l|c|l|}
\hline Year & $\begin{array}{l}\text { Number of the } \\
\text { enthusiasts }\end{array}$ & $\begin{array}{l}\text { Number of the } \\
\text { registered }\end{array}$ \\
\hline 2015 & 1048 & 1009 \\
\hline 2016 & 1386 & 1370 \\
\hline 2017 & 1470 & 1442 \\
\hline
\end{tabular}

\section{Data Processing (Data Preparation Phase)}

This part presents, the data that it is includes data processing that is data for New Student Admissions for $2015^{\text {th }}$ to $2017^{\text {th }}$. This part is includes some several processes, including:

\section{Data Selection}

In this process, several attributes were selected to be used for modeling, namely, Gender, School, Department, Wave, Department Choice (2 choices), notes, Religion, Department of graduation, Address and Parents' Occupation.

\section{Data Cleaning}

Initial data does not all contain complete or complete data. So it is necessary to do a cleaning process, where the blank data is removed so that the remaining data is ready to be processed.

\section{Data Change}

At this part, there are several attributes in the data that also can be simplified into a new attributes. Then the value of the conversion for the required attributes is also carried out.

\section{Modeling}


This part will be explain about the use of the Data Mining technique with the prediction method by using the $\mathrm{C} 45$ algorithm and Nearest Neighbor, which produces the prediction rules and the most influential variables in predicting the entry of prospective new students.

\section{Evaluation}

In this part, it is about an evaluation that is carried out to obtain the quality and effectiveness of the model used, then the prediction results are obtained for each prediction algorithm. The prediction results are then tested for the level of accuracy with the help of the confusion matrix method. After that, the process of comparing the level of accuracy of each algorithm is carried out to determine which algorithm has the highest accuracy.

\section{Deployment Phase}

From the existing results, at this stage there will be a dissemination in the form of making reports and it can be implemented to the Muhammadiyah University of Gorontalo as a reference in predicting the number of incoming new student candidates in the future.

\section{Results and Discussion}

\section{The C4.5 Algorithm Calculation Results}

The C4.5 algoritma is one the most effective decision algorithms for classification. The dicision tree is built by recursively dividing the data until each part consists of data from the same class (Iskandar \& Suprapto, 2016)

Specifically, the C4.5 Decision Tree algorithm uses a modified split criterion called Gain Ration in the split attribute selection process (Jovanovic et al., 2012; Dongming et al., 2016; Mishra et al., 2016; Wang et al., 2019). In this algorithm, it is an algorithm that is used to form a decision tree which is, that consists of a set of rules to divide into a number of populations into a smaller ones.

\begin{tabular}{|c|c|c|c|c|c|}
\hline & Attribute & $\begin{array}{l}\text { The } \\
\text { Number }\end{array}$ & Pass & $\begin{array}{l}\text { Year } \\
\text { of } \\
\text { pass }\end{array}$ & Entropy \\
\hline & Total & 4431 & 3748 & 683 & 0.62011 \\
\hline Gender & Male & 1228 & 058 & 70 & 0.58013 \\
\hline & Female & 3203 & 2690 & 13 & 0.63470 \\
\hline & Agribusiness (AGB) & 86 & 1 & 5 & 0.66771 \\
\hline & Accountancy & 87 & 67 & 0 & 0.77781 \\
\hline $\begin{array}{l}\text { The Choices } \\
\text { of }\end{array}$ & $\begin{array}{l}\text { Primary of Education Teacher } \\
\text { (PGSD) }\end{array}$ & 477 & 438 & 9 & 0.40835 \\
\hline Department & Information System (SI) & 179 & 155 & 4 & 0.56852 \\
\hline & $\ldots .$. & .... & .... & .... & .... \\
\hline & English Literature (ELITE) & 93 & 4 & 9 & 0.73045 \\
\hline & Senior High School (MA) & 305 & 259 & 6 & 0.61189 \\
\hline $\begin{array}{l}\text { Last } \\
\text { Education }\end{array}$ & $\begin{array}{l}\begin{array}{l}\text { Vocational High } \\
\text { (SMK) }\end{array} \\
\text { School } \\
\end{array}$ & 729 & 07 & 2 & 0.65161 \\
\hline & Senior High School & 3397 & 882 & 5 & 0.61384 \\
\hline Major & Office administration & 94 & 9 & 5 & 0.83560 \\
\hline of School & Religion & 4 & 2 & 2 & 1 \\
\hline & Agribusiness Processing of & 11 & 8 & 3 & 0.84535 \\
\hline
\end{tabular}




\begin{tabular}{|l|l|l|l|l|l|}
\hline & Agricultural Products & & & & \\
\cline { 2 - 6 } & $\ldots$ & $\ldots$ & $\ldots$ & $\ldots$ & $\ldots$ \\
\cline { 2 - 6 } & $\begin{array}{l}\text { Agricultural Product } \\
\text { Processing Technology }\end{array}$ & 21 & 4 & 7 & 0.70247 \\
\cline { 2 - 6 } Total of Exam & Travel agent & 2 & 2 & 0 & 0 \\
\hline & Not Following the exam & 77 & 0 & 0 & 0 \\
\cline { 2 - 7 } & $<70$ & 631 & 96 & 19 & 0.94316 \\
\cline { 2 - 7 } & $<80$ & 1453 & 1407 & 0 & 0 \\
\cline { 2 - 7 } & 1679 & 657 & 2 & 0.10073 \\
\hline
\end{tabular}

The total row of the Entropy column is calculated by the following equation below:

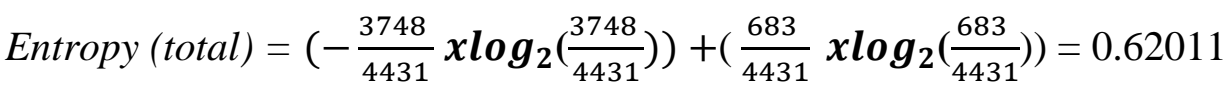

Meanwhile, the gain value for gender is calculated by the following equation below:

Gain $($ total, gender $)=$ Entropy $($ total $)-\sum_{i=1}^{n} \frac{\text { gender }}{\text { total }} x$ Entropy $($ gender $)$

Gain $($ total, gender $)=0.62011-\left(\left(\frac{1228}{4431} x 0.58013\right)+\left(\frac{3203}{4431} x 0.63470\right)\right)=0.00053$

From the calculation results contained in the node calculation table, it can be seen that the highest gain is found in the total test attribute, which is 0.44763 . Thus the test total can be the root node. And in the total test there are 4 attribute values from which the results can be described as a temporary decision tree as follows:

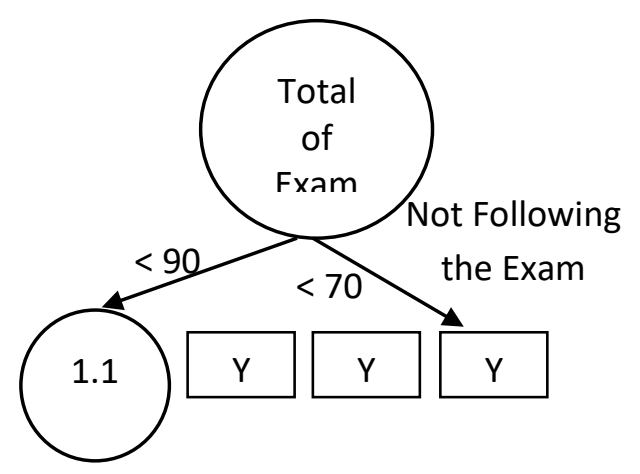

The results also look like the same, when we test using the Rapid-miner tools which are shown in the following image below: 


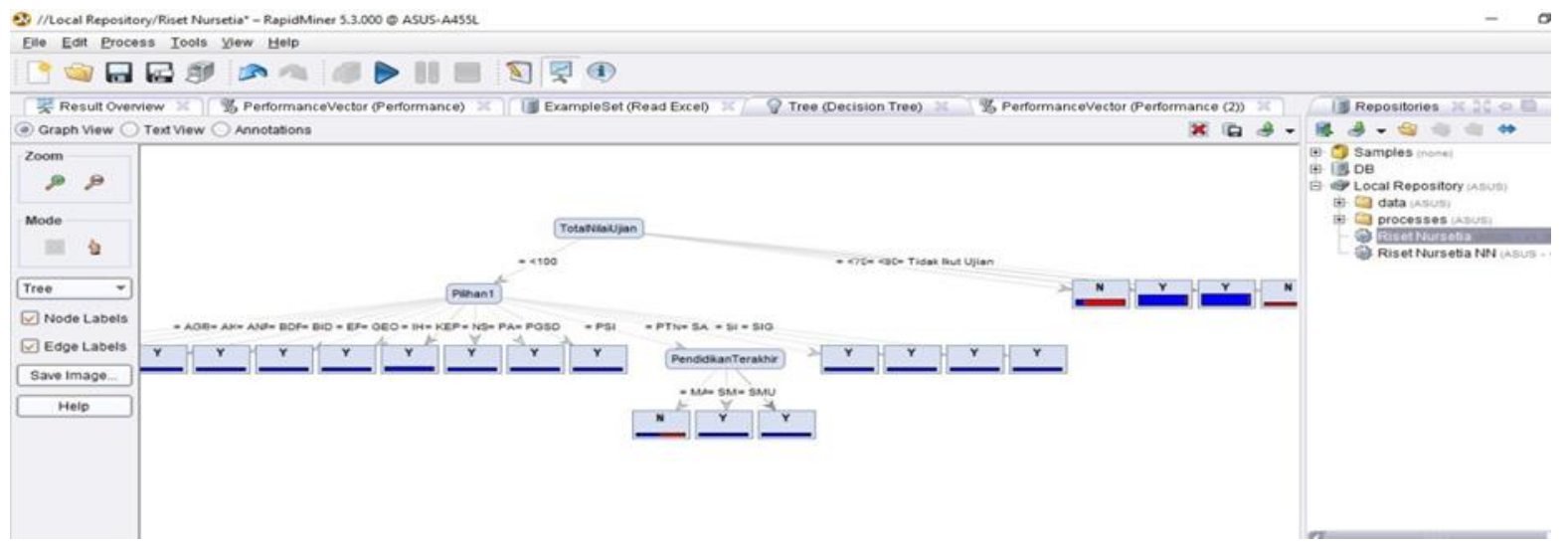

\section{Nearest Neighbor Algorithm Calculation Results}

This algorithm uses an approach to searching for cases by calculating the closeness between a new cases and old cases which is, it is based on matching the weights from a number of an existing features.

Table of the Old Case

\begin{tabular}{|c|l|l|c|}
\hline Gender & Last Education & Religion & $\begin{array}{l}\text { Pass } \\
\text { Examination }\end{array}$ \\
\hline Male & Vocational High School (SMK) & Hindu & Y \\
\hline Female & Senior High School & Islam & N \\
\hline Female & Senior High School & Islam & Y \\
\hline
\end{tabular}

The attribute of passing the test is an attribute of the goal. The weights between one attribute and another on non-goal attributes can be defined with different values.

Attribute Table of Weight Definition

\begin{tabular}{|l|l|}
\hline Attribute & Weight \\
\hline Gender & 0.5 \\
\hline Last Education & 1 \\
\hline Religion & 0.75 \\
\hline
\end{tabular}

Proximity Table of Gender Attribute Value

\begin{tabular}{|l|l|l|}
\hline $\begin{array}{c}\text { Score } \\
\mathbf{1}\end{array}$ & $\begin{array}{l}\text { Score } \\
\mathbf{2}\end{array}$ & Proximity \\
\hline Female & Female & 1 \\
\hline Male & Male & 1 \\
\hline Female & Male & 0.5 \\
\hline Male & Female & 0.5 \\
\hline
\end{tabular}

Table of Last Education Attribute Value Proximity

\begin{tabular}{|l|l|l|}
\hline Value 1 & Value 2 & Proximity \\
\hline Vocational high School (SMK) & $\begin{array}{l}\text { Vocational high School } \\
(\text { SMK) }\end{array}$ & 1 \\
\hline Senior High School (SMU) & Senior High School (SMU) & 1 \\
\hline Senior High School (SMU) & Vocational high School & 0.4 \\
\hline
\end{tabular}




\begin{tabular}{|l|l|l|}
\hline & (SMK) & \\
\hline Vocational high School (SMK) & Senior High School (SMU) & 0.4 \\
\hline
\end{tabular}

\section{Proximity Table of Religious Attribute Values}

\begin{tabular}{|l|l|l|}
\hline Score 1 & Score 2 & Proximity \\
\hline Hindu & Hindu & 1 \\
\hline Islam & Islam & 1 \\
\hline Hindu & Islam & 0.75 \\
\hline Islam & Hindu & 0.75 \\
\hline
\end{tabular}

New Case

Gender

: Male

Last Education

: Vocational High School (SMK)

Religion

: Hindu

To predict whether the prospective new student will pass the exam or not, use the following steps:

Calculate the closeness of the new case to the old case. Known as: (a) Proximity of gender attribute values (Male to Male) 1 (b) Weight Attribute Gender 0.5 (c) The closeness of the last educational attribute values (SMK and SMU) 0.4 (d) Last educational attribute weights (e) Proximity of religious attribute values (Hinduism and Hinduism) 1 (f) The Weight of Religious Attributes 0.75

Counted:

$$
\begin{aligned}
& \text { Range }=\frac{(a * b)+(c * d)+(e * f)}{b+d+f} \\
& \text { Range }=\frac{(1 * 0.5)+(0.4 * 1)+(1 * 0.75)}{0.5+1+0.75} \\
& \text { Range }=\frac{1.65}{2.25} \\
& \text { Range }=0.73
\end{aligned}
$$

Calculating the closeness of the new case with the case of number 2. Known as: (a) Proximity of gender attribute values (Female to Male) 0. (b) Weight Attribute Gender 0.5 (c) The closeness of the last educational attribute values (SMK and SMU) 0.4 (d) Last educational attribute weights 1 (e) The proximity of the value of religious attributes (Islam and Islam) 1 (f) The Weight of Religious Attributes 0.75

Counted:

$$
\begin{aligned}
& \text { Range }=\frac{(a * b)+(c * d)+(e * f)}{b+d+f} \\
& \text { Range }=\frac{(0.5 * 0.5)+(0.4 * 1)+(1 * 0.75)}{0.5+1+0.75} \\
& \text { Range }=\quad \frac{1.4}{2.25} \\
& \text { Range }=0.62
\end{aligned}
$$

Calculating the closeness of the new case to case number 3 
Known: (a) Proximity of gender attribute values (Female to Male) 0.5 (b) Weight Attribute Gender 0.5 (c) The closeness of the last educational attribute values (SMK and SMU) 0.4 (d) Last educational attribute weights 1 (e) The closeness of the religious attribute values (Hinduism and Islam) 0.75 (f) The Weight of Religious Attributes 0.75

Counted:

Range $=\frac{(a * b)+(c * d)+(e * f)}{b+d+f}$
Range $=\frac{(0.5 * 0.5)+(0.4 * 1)+(0.75 * 0.75)}{0.5+1+0.75}$
Range $=\frac{2.15}{2.25}$
Range $=0.95$

Selecting the case with the closest proximity.

From steps $1^{\text {st }}, 2^{\text {nd }}$ and $3^{\text {rd }}$ it can be seen that the highest value is in the case number 3 , therefore the closest case to new case is case 3 .

\section{Uses the classification of cases with the closest proximity.}

Based on the results of step 4, the case of number 3 will be used to predict new cases with the possibility that new students will pass the exam. The following explanation below are the results of the Nearest Neighbor algorithm using real data using Excel:

\section{Proximity of the Gender}

Attribute Values

\begin{tabular}{|l|l|c|}
\hline $\begin{array}{l}\text { Value } \\
\mathbf{1}\end{array}$ & $\begin{array}{l}\text { Value } \\
\mathbf{2}\end{array}$ & Proximity \\
\hline Male & Male & 1 \\
\hline Female & Female & 1 \\
\hline Female & Female & 0.5 \\
\hline Female & Male & 0.5 \\
& & \\
\hline
\end{tabular}

Proximity of Religious Attribute Values

\begin{tabular}{|l|l|c|}
\hline Nilai 1 & Nilai 2 & Bobot \\
\hline Hindu & Kristen & 0.75 \\
\hline Islam & Hindu & 0.75 \\
\hline Kristen & Islam & 0.75 \\
\hline Hindu & Hindu & 1 \\
\hline Islam & Islam & 1 \\
\hline Kristen & Kristen & 1 \\
\hline
\end{tabular}

Proximity of the Educational Attribute Values

\begin{tabular}{|c|l|c|}
\hline Value 1 & Value 2 & Weight \\
\hline Senior High School (MA) & Vocational high School & 0.4 \\
\hline
\end{tabular}




\begin{tabular}{|l|l|c|} 
& $($ SMK) & \\
\hline Senior High School & Senior High School & 0.4 \\
\hline $\begin{array}{l}\text { Vocational high School } \\
\text { (SMK) }\end{array}$ & Senior High School & 0.4 \\
\hline Senior High School (MA) & Senior High School (MA) & 1 \\
\hline Senior High School School & $\begin{array}{l}\text { Vecational high School } \\
\text { (SMK) }\end{array}$ & 1 \\
\hline $\begin{array}{l}\text { Vocational high } \\
(\text { SMK) }\end{array}$ & 1 \\
\hline
\end{tabular}

\begin{tabular}{|l|l|l|}
\hline Gender & Religion & Last Education \\
\hline Female & I & $\begin{array}{l}\text { Senior High } \\
\text { School (SMU) }\end{array}$ \\
\hline
\end{tabular}

Table of Case

\begin{tabular}{|l|l|l|}
\hline Gender & Religion & Last Education \\
\hline Female & I & Senior High School (SMU) \\
\hline Female & I & Senior High School (SMU) \\
\hline Female & I & Senior High School (SMU) \\
\hline Male & I ... & Senior High School (MA) \\
\hline Female & I & Senior High School (MA) \\
\hline Male & Christ & Senior High School (SMU) \\
\hline Female & I & $\begin{array}{l}\text { Vocational High School } \\
\text { (SMK) }\end{array}$ \\
\hline Male & I & Senior High School (SMU) \\
\hline Male & I & Senior High School (SMU) \\
\hline Male & I & Senior High School (MA) \\
\hline Female & I & Senior High School (SMU) \\
\hline Female & I & Senior High School (SMU) \\
\hline Male & I & Senior High School (SMU) \\
\hline Male & Christ & Senior High School (SMU) \\
\hline Male & I & Senior High School (SMU) \\
\hline Female & I & Senior High School (MA) \\
\hline Male & I & Senior High School (SMU) \\
\hline Male & I & Senior High School (SMU) \\
\hline
\end{tabular}




\begin{tabular}{|c|c|c|c|c|c|c|c|}
\hline Number & $\begin{array}{l}\text { Proximity } \\
\text { of Gender } \\
\text { Attribute } \\
\text { Value }\end{array}$ & $\begin{array}{c}\text { Gender } \\
\text { Attribute } \\
\text { Weights }\end{array}$ & $\begin{array}{c}\text { Proximity of } \\
\text { Religious } \\
\text { Attribute } \\
\text { Values }\end{array}$ & $\begin{array}{l}\text { Weight of } \\
\text { Religious } \\
\text { Attributes }\end{array}$ & $\begin{array}{l}\text { Proximity } \\
\text { of } \\
\text { Educational } \\
\text { Attribute } \\
\text { Values }\end{array}$ & $\begin{array}{c}\text { Education } \\
\text { Attribute } \\
\text { Weights }\end{array}$ & $\begin{array}{c}\text { The Formula of } \\
\text { Range }\end{array}$ \\
\hline 1 & 1 & 0.5 & 1 & 0.75 & 1 & 1 & 1 \\
\hline 2 & 1 & 0.5 & 1 & 0.75 & 1 & 1 & 1 \\
\hline 3 & 1 & 0.5 & 1 & 0.75 & 1 & 1 & 1 \\
\hline 4 & 1 & 0.5 & 1 & 0.75 & 1 & 1 & 1 \\
\hline 5 & 0.5 & 0.5 & 1 & 0.75 & 1 & 1 & 0.888888889 \\
\hline 6 & 1 & 0.5 & 1 & 0.75 & 0.4 & 1 & 0.733333333 \\
\hline $\begin{array}{c}\ldots \\
333\end{array}$ & $\begin{array}{l}\ldots \\
0.5\end{array}$ & $\begin{array}{l}\ldots \\
0.5\end{array}$ & $\frac{\ldots}{1}$ & $\frac{\ldots}{0.75}$ & $\begin{array}{c}\ldots \\
0.4\end{array}$ & $\ldots$ & 0.433333333 \\
\hline 334 & 1 & 0.5 & 1 & 0.75 & 1 & 1 & 1 \\
\hline 335 & 0.5 & 0.5 & 0.75 & 0.75 & 0.4 & 1 & 0.433333333 \\
\hline 336 & 1 & 0.5 & 1 & 0.75 & 0.4 & 1 & 0.6 \\
\hline 337 & 0.5 & 0.5 & 0.75 & 0.75 & 0.4 & 1 & 0.433333333 \\
\hline 338 & 0.5 & 0.5 & 1 & 0.75 & 0.4 & 1 & 0.433333333 \\
\hline 339 & 0.5 & 0.5 & 1 & 0.75 & 0.4 & 1 & 0.433333333 \\
\hline 340 & 1 & 0.5 & 1 & 0.75 & 0.4 & 1 & 0.6 \\
\hline 341 & 0.5 & 0.5 & 0.75 & 0.75 & 1 & 1 & 0.833333333 \\
\hline 342 & 0.5 & 0.5 & 1 & 0.75 & 0.4 & 1 & 0.433333333 \\
\hline 343 & 0.5 & 0.5 & 1 & 0.75 & 1 & 1 & 0.833333333 \\
\hline 344 & 0.5 & 0.5 & 1 & 0.75 & 1 & 1 & 0.833333333 \\
\hline 345 & 1 & 0.5 & 1 & 0.75 & 0.4 & 1 & 0.6 \\
\hline 346 & 1 & 0.5 & 1 & 0.75 & 1 & 1 & 1 \\
\hline 347 & 1 & 0.5 & 1 & 0.75 & 1 & 1 & 1 \\
\hline 348 & 0.5 & 0.5 & 1 & 0.75 & 0.4 & 1 & 0.433333333 \\
\hline 349 & 0.5 & 0.5 & 0.75 & 0.75 & 1 & 1 & 0.833333333 \\
\hline 350 & 0.5 & 0.5 & 1 & 0.75 & 1 & 1 & 0.833333333 \\
\hline 351 & 1 & 0.5 & & 0.75 & 0.4 & 1 & 0.6 \\
\hline
\end{tabular}

The Following table below is the results of using the Rapid-Miner Tool:
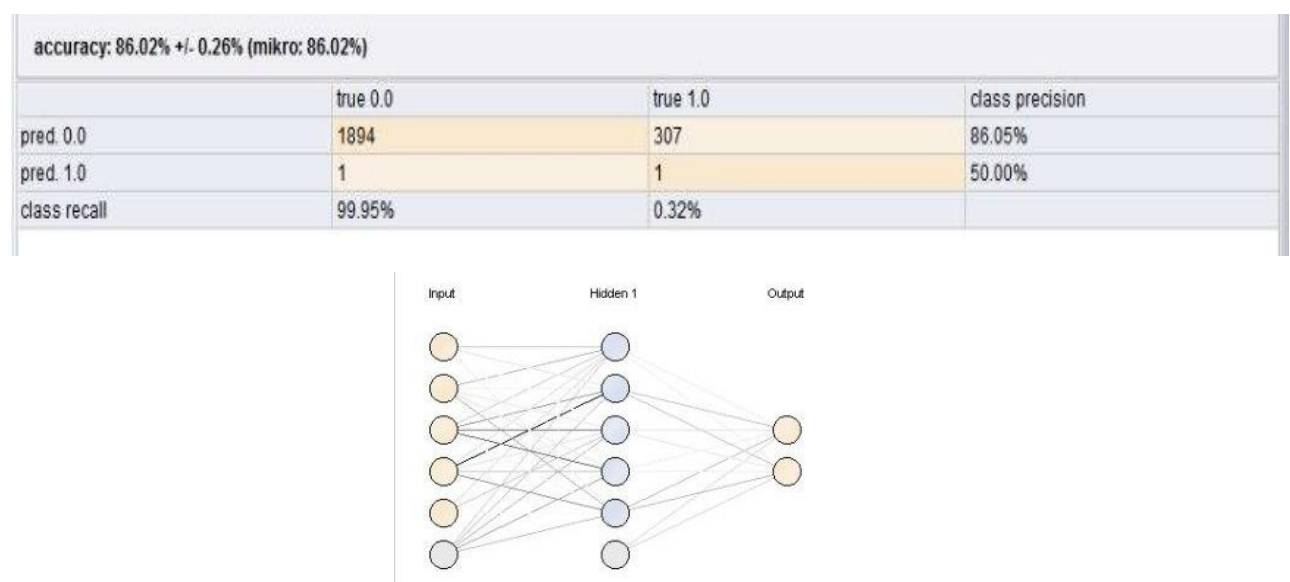


\section{Algorithm C4.5}

The conclusion of the $C 4.5$ algorithm will be show up in the picture below; the accuracy that has been obtained is $96.47 \%$ with the Yes Prediction (Y) as true yes 4743 and true no 76 and also, in $98.42 \%$ as Precision class and Prediction No (N) yes itself as 122 and True no is 670 with the Class Precision $84.60 \%$.

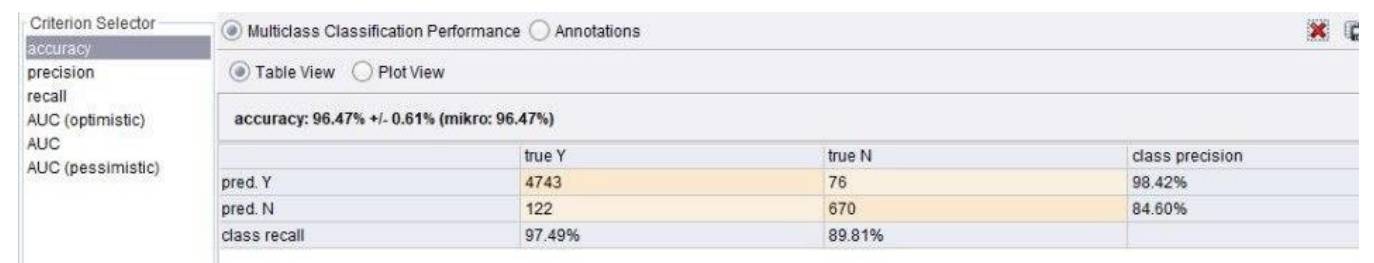

\section{Nearest Neighbor Algorithm}

In the picture below, the accuracy of value of the Nearest Neighbor Algorithm is $86.02 \%$ with the result of precision class is $86.05 \%$ and a precision class is $50.00 \%$.

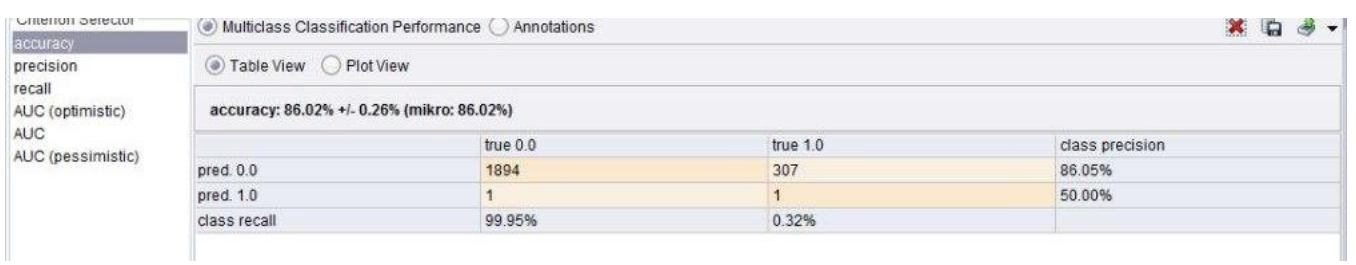

Based from both images above, it is very clear that the highest accuracy is in the $C 4.5$ Algorithm itself. Because, according to the researchers' analysis that has been explained on the finding and discussion on this research, the C4.5 algorithm is in processing of the calculations, through the Rapid Miner tools in particular, it does not require to the process of changing the original data itself. Meanwhile, from data that is containing letters and numbers, while for the Nearest Neighbor algorithm, the process of changing the data is very necessary because, when processing the algorithm then it must be numerical and for other reasons, that is the Nearest Neighbor algorithm is more widely used for the classification process according to the proximity of values.

\section{Conclusion}

It is clear when the comparison between both of the algorithms itself is superior to the C4.5 algorithm, which in the decision tree is the top node in the Total test of attribute, meanwhile, it is seen in real data when researchers and the researcher's assistant is perform the data collection in a very differently way, with what has been expected, it is the amount of blank data that is redundant their data when new students fill in their data, especially on the attributes of the origin of the department during school and their Pure Eptanas Score (NEM) or the final scores, which are important attributes in determining the best results.

\section{References}

Dongming, L., Yan, L., Chao, Y., Chaoran, L., Huan, L., \& Lijuan, Z. (2016, October). The Dongming, L., Yan, L., Chao, Y., Chaoran, L., Huan, L., \& Lijuan, Z. (2016, October). The application of decision tree C4. 5 algorithm to soil quality grade forecasting model. In 2016 First IEEE International Conference on Computer Communication and the Internet (ICCCI) (pp. 552-555). IEEE. 
Hartatik, H. (2015). Penerapan Algoritma Learning Vector Quantization Untuk Prediksi Nilai Akademis Menggunakan Instrumen Ams (Academic Motivation Scale). Data Manajemen dan Teknologi Informasi (DASI), 16(3), 53.

Iskandar, D., \& Suprapto, Y. K. (2016). Perbandingan Akurasi Klasifikasi Tingkat Kemiskinan Antara Algoritma C 4.5 Dan Naïve Bayes. Network Engineering Research Operation, 2(1).

Jovanovic, M., Vukicevic, M., Milovanovic, M., \& Minovic, M. (2012). Using data mining on student behavior and cognitive style data for improving e-learning systems: a case study. International Journal of Computational Intelligence Systems, 5(3), 597-610.

Kurgan, L. A., \& Musilek, P. (2006). A survey of knowledge discovery and data mining process models. Knowledge Engineering Review, 21(1), 1-24.

Kusrini, E. T. L. (2009). Algoritma data mining. Yogyakarta: Andi Offset.

Mariscal, G., Marban, O., \& Fernandez, C. (2010). A survey of data mining and knowledge discovery process models and methodologies. The Knowledge Engineering Review, 25(2), 137.

Mishra, T., Kumar, D., \& Gupta, S. (2016). Students' employability prediction model through data mining. International Journal of Applied Engineering Research, 11(4), 22752282.

Retnosari, P., \& Jananto, A. (2013). Implementasi Data Mining Untuk Menemukan Hubungan Antara Kota Kelahiran Mahasiswa Dengan Tingkat Kelulusan Mahasiswa Pada Fakultas Teknologi Informasi Unisbank. Journal of Dinamika Informatika, 5(2), 112-121.

Wang, X., Zhou, C., \& Xu, X. (2019). Application of C4. 5 decision tree for scholarship evaluations. Procedia Computer Science, 151, 179-184. 